\title{
First report of Septoria silybi associated with leaf blotch of Silybum marianum from Iran
}

\author{
Samad Jamali
}

\begin{abstract}
During March to April 2013, in the course of routine sample collection, a leaf spot disease was observed on Silybum marianum in different areas of Kermanshah province, Iran. Initial symptoms of the disease were pale brown, necrotic lesions, mostly 8-10 mm long on leaves. On the surface of the infected leaves conidiomata were observed, which were pycnidial, amphigenous, scattered, dark brown to blackish, globose, immersed in host tissue, becoming partly erumpent, unilocular, $90-150 \mu \mathrm{m}$ in diameter, with an ostiole of 18-24 $\mu \mathrm{m}$ in diameter. Conidiogenesis was enteroblastic. Conidia were hyaline, filiform, sub-straight to mildly flexuous, truncate at the base, $20-48 \times 1.2-2.8 \mu \mathrm{m}, 2-5$-septate, with indistinct septa. On the basis of symptoms, fungal morphology and completion of Koch's postulate, the fungal isolates from the leaf spots were identified as Septoria silybi. This is the first report of $S$. silybi on leaves of $S$. marianum in Iran.
\end{abstract}

Keywords: Septoria silybi; Silybum marianum; leaf blotch; Iran mycobiota

\section{Introduction}

Milk thistle [Silybum marianum (L.) Gaertn.] is an annual or biannual plant native to the Mediterranean region and belongs to the Asteraceae family. $S$. marianum is widespread in the East, South and West of

Received: 15 September 2014

Accepted revised version: 11 November 2014

Published online: 1 January 2015

(C) Jamali (2015)

Publisher: Horizon e-Publishing Group

\section{CITATION}

Jamali, S. 2015. First report of Septoria silybi associated with leaf blotch of Silybum marianum from Iran. Plant Science Today 2: 21-23. doi: 10.14719/pst.2015.2.1.82

AUTHOR'S AFFILIATION

Department of Plant Protection, College of Agriculture, Razi University, Kermanshah, Iran. P.O.Box:6715685438.

CORRESPONDENCE

Dr. Samad Jamali Email: Jamali454@yahoo.com
Iran, where it invades land disturbed by grazing, machinery, or natural erosion. Milk thistle is an ancient medicinal plant used to purify and protect the liver as early as 23-79 AD. Milk thistle positively affects all forms of liver disease. The active chemical component of milk thistle is silymarin, which is a combination of three flavonoids. The seeds contain the highest amount of silymarin, but the whole plant is used medicinally. Silybin (part of the chemical structure of silymarin) is an antioxidant; it also alters the membrane structure of the liver cells, blocking the absorption of penetrating toxins into the cell (Morazzoni and Bombardelli, 1995). Silybin stimulates the production of new liver cells to replace damaged cells (kcweb.com/herb/milkt.htm). Silicristin inhibits the enzymes peroxidase and lipoxygenase (Francis, 1981). The genus Septoria Sacc. belongs to sympodial Blastopycnidiineae of Coelomycetes, Fungi Imperfecti (Sutton, 1980).

The genus Septoria has reported to include more than 1000 (Kirk et al., 2001) to 2000 (Markevicius, 1996) species distributed all over the World. All species of this genus are plant pathogens causing a range of disease symptoms including leaf and fruit spots in agricultural crops, as well as horticultural and native plants (Moscow and Lindow, 1989). These damages affect the vitality and biological productivity of the attacked plants. In a survey conducted during March to April 2013 in Kermanshah province, symptoms of Septoria leaf blotch were observed on milk thistle plants. Initial symptoms of the disease were pale brown necrotic lesions, mostly 8-10 $\mathrm{mm}$ long on leaves. Therefore, present investigation was carried out to study the morphology and cause of leaf blotch infection on $S$. marianum.

\section{Materials and Methods}

The infected leaf samples were collected in different localities and natural habitats in Kermanshah province, taken to the laboratory; air dried and examined using standard light microscopy. The fungus was isolated from pycnidia (pycniospores) on leaves of $S$. marianum 


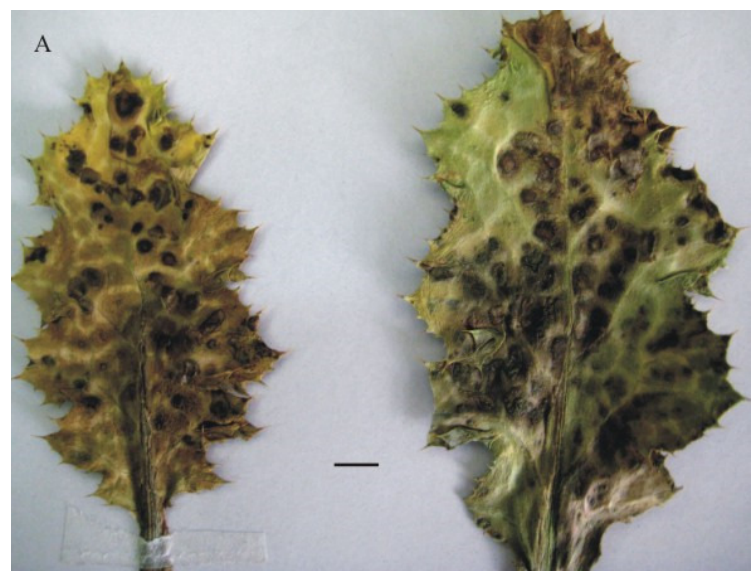

Fig. 1. Leaf spots on the leaves of Silybum marianum infected with Septoria silybi. Bar $=1 \mathrm{~cm}$

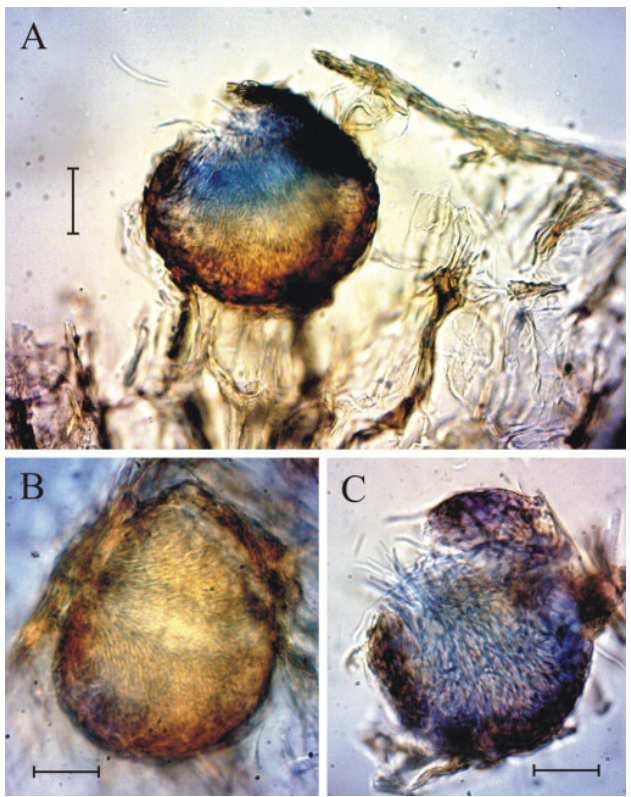

Fig. 2. A, B, Pycnidium immersed in host tissue and C, on the leaf lesion. Bars $=25 \mu \mathrm{m}$

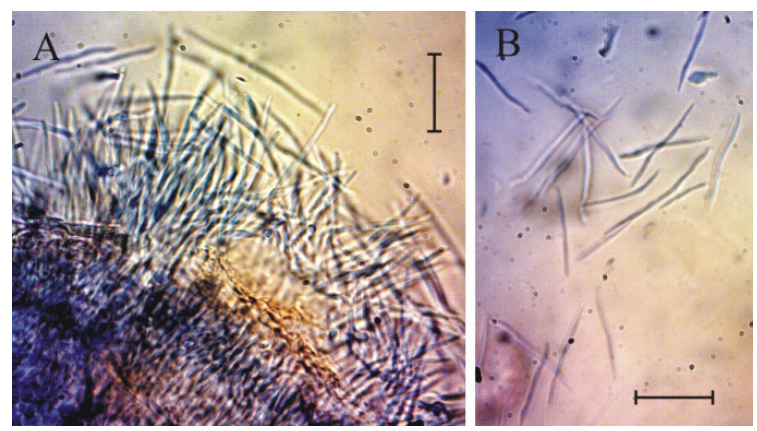

Fig. 3. A, B, Filiform conidia. Bars $=25 \mu \mathrm{m}$

and cultivated in vitro. Pycniospores were placed under aseptic conditions on $2 \%$ potato dextrose agar (PDA) plates supplemented with $20 \mu \mathrm{g} / \mathrm{ml}$ of streptomycin sulphate. Plates were incubated at $25-27^{\circ} \mathrm{C}$ in dark for 14 days to allow the fungi to grow. For fungal identification, during the incubation period, plates were observed daily for the appearance of fungal colonies. Morphological characteristics of the fungus such as size, shape, septation of conidia, conidiomatal type, conidiogenesis and conidiogenous cells were recorded. Fifty measurements of each type of structure were made using BioloMICSMeasure software. The identification was carried out comparing the information registered with those published in the specialized literature (Teterevnikova-Babayan, 1987; Vanev et al., 1997; Kirk et al., 2001; Priest, 2006). The voucher specimens are housed at Razi University (SeSi-1) and a conidial isolate is kept in the Iranian Research Institute of Plant Protection. The pathogenicity tests were done with a suspension of $1 \times 10^{6}$ conidia per $\mathrm{ml}$ homogenized in sterile water. Conidial suspension was sprayed on 4 to 5 , fully expanded, healthy leaves of five potted $S$. marianum plants. For the control, three $S$. marianum plants were sprayed with sterilized, distilled water and were placed $100 \mathrm{~m}$ away from the inoculated plants in a green house. Plants were covered with plastic sheets to maintain humidity and kept in a greenhouse for 48 hours and removed after 48 hours. Three non-inoculated plants served as a control.

\section{Results and Discussion}

In natural habitats, leaf lesions were round, irregular or angular, often delimited by veins, 2-5 $\mathrm{mm}$ in diameter, sometimes up to $10 \mathrm{~mm}$ or more when coalesced, pale brown to grayish with darker border zone and white in the center (Fig. 1A). On the surface of the infected leaves conidiomata were observed, which were pycnidial, amphigenous, but mostly epigenous, scattered, dark brown to blackish, globose, immersed in host tissue, becoming partly erumpent, separate, unilocular, $90-150 \mu \mathrm{m}$ in diameter, with an ostiole of 18-24 $\mu \mathrm{m}$ in diameter (Fig. 2A, B, C). Conidiogenesis was enteroblastic. Conidia were hyaline, filiform, sub-straight to mildly flexuous, truncate at the base, 20-48 × 1.2-2.8 $\mu \mathrm{m}(\mathrm{n}=50), 2-5$-septate, with indistinct septa (Fig. 3A, B). No teleomorphic state was observed. Based on the morphological characteristics the pathogen was identified as $S$. silybi (Teterevnikova-Babayan, 1987; Vanev et al., 1997; Priest, 2006). Mycelium of isolates of S. silybi were slow growing on potato dextrose agar and the upper side of colony was dark colored. Pycnidial conidiomata with conidia were formed in cultures after at least two weeks of incubation.

Pathogenicity of the fungal isolate was confirmed by inoculating $S$. marianum with a conidial suspension of S. silybi. After 14 days, leaf spots, similar to those 
observed on naturally infected plants, started to develop on the leaves of inoculated plants. S. silybi was the only fungus consistently isolated from the leaves of experimentally infected plants, which demonstrated that it was the cause of blotch spot of $S$. marianum. The fungal sporulation was examined and found morphologically the same as the originally described pathogen. No Septoria was isolated from any of the control plants. In a recent book Fungi of Iran, 86 species of septoria collected from Iran were listed (Ershad, 2009). In Iran, Golovinomyces cichoracearum, Leveilula taurica and Sclerotinia sclerotiorum were reported from S. marianum (Yazdani and Abbasi, 1998; Aghajani et al., 2008), and there have been no previous records of Septoria or Septoria-like fungi on $S$. marianum. This is the first report of $S$. silybi as well as its host plant (S. marianum) in Iran. The infected plants were observed in plant populations on all parts of studied territory. Up to 30 percent of plant populations infected with the fungus. S. silybi has been previously recorded on $S$. marianum in central California, Bulgaria and other countries (Moscow and Lindow, 1989). $S$. silybi was reported as the only Septoria pathogen of milk thistle and give $S$. marianum as the sole host known for S. silybi (Saccardo, 1884; Oudemans, 1923).

\section{References}

Aghajani, M. A., L. Torbati, and A. Kolasaagiani. 2008. Occurrence of charcoal rot on kiwi fruit in Iran. 18 th Iraninan Plant Protection Congress, Hamedan, Iran. p. 190.

Ershad, J. 2009. Fungi of Iran. Ministry of Jihad-e-Agriculture, Agricultural Research, Education and Extension Organization, Iran. 531pp.

Francis, R. 1981. The Wild Flower Key. Frederick Warne \& Co, 576pp.

Kirk, P. M., P. F. Cannon, J. C. David, and J. A. Stalpers. 2001. Ainsworth and Bisby's Dictionary of The Fungi. CABI Publishing, Cambridge.

Markevicius, V. 1996. New data on the fungi of Septoria Fr. Genus in Lithuania. Botanica Lithuanica 2: 49-63

Morazzoni, P., and E. Bombardelli. 1995. Silybum marianum (Carduus marianus). Fitoterapia 66: 3-42

Moscow, D., and S. E. Lindow. 1989. Infection of Milk Thistle (Silybum marianum) Leaves by Septoria silybi. Phytopathology 79: 1085-1090. doi: 10.1094/Phyto-79-1085

Oudemans, C. A. J. A. 1923. Enumeratio Systemica Fungorum, Austria. Vol 4.

Priest, M. J. 2006. Fungi of Australia - Septoria. CSIRO Publishing, Melbourne, Australia. 268pp.

Saccardo, P. A. 1884. Sylloge Fungorum. Friedlander and Sohn, Berlin. Vol 3.

Sutton, B. C. 1980. The Coelomycetes: fungi imperfecti with pycnidia, acervuli, and stromata. Commonwealth Mycological Institute, Surrey.

Teterevnikova-Babayan, D. N. 1987. Fungi of the genus Septoria in USSR. Erevan, AS Armenian SSR. 480pp.

Vanev, S. G., E. F. Sameva, and G. G. Bakalova. 1997. Order
Sphaeropsidales - Fungi Bulgaricae Vol 3, 1-335pp.

Yazdani, D., and M. Abbasi. 1998. Identification of several powdery mildew diseases affecting cultivated medicinal plants in Karaj-Tehran. 13th Iraninan Plant Protection Congress, Karaj, Iran. p. 207. 